\title{
KAJIAN HUKUM ADAT TERHADAP KONFLIK ANTAR NEGERI DI MALUKU TENGAH (STUDI DI KECAMATAN JAZIRAH LEIHITU KABUPATEN MALUKU TENGAH)
}

\author{
Judy Marria Saimima1 \\ ${ }^{1}$ Program Studi Ilmu Hukum, Universitas Pattimura \\ Email: judymarria@gmail.com
}

\begin{abstract}
ABSTRAK
Pembangunan hukum yang berkarakter sesuai ciri kehidupan masyarakat Maluku yang plural dan dinamis, membutuhkan perhatian serius dari pembentuknya. Artinya aturan hukum yang dibentuk bukan sekedar memenuhi target dan mengindikasikan sebuah prestise dan prestasi dari pembentuknya namun hukum harus merupakan cerminan dari kebutuhan kehidupan masyarakat. Pengendalian hukum adat merupakan cara berdasarkan norma-norma hukum adat untuk mencegah hal-hal yang tidak diinginkan, termasuk konflik antar negeri. Penelitian ini bertujuan menganalisis dan membahas upaya pengendalian hukum adat di Maluku dalam mengatasi berbagai bentuk perkelahian antar negeri, khususnya di Kecamatan Jazirah Leihitu Kabupaten Maluku Tengah. Penelitian ini adalah sebuah penelitian hukum yuridis sosiologis dengan metode deskripsi analisis. Sumber data adalah data kepustakaan dan wawancara kolektif. Hasil penelitian menunjukan bahwa ikatan genealogis memegang peranan penting dalam memelihara nilai kebersamaan dan kesetiaan. Fungsi Raja sebagai pengendali hukum adat antar negeri belum sepenuhnya berfungsi dengan baik dan maksimal. Sistem pengendalian hukum adat tidak dapat berfungsi dengan baik disebabkan oleh karena ketidakmampuan Raja Negeri untuk mengendalikan suatu kondisi yang dapat memicu terjadinya perkelahian yang kemungkinan berdampak menjadi luas serta pemahaman tentang soal-soal penegakan hukum adat yang sistematik tidak dipahami dengan baik oleh Raja-Raja Negeri. Sangat dibutuhkan dukungan politik dari Pemerintah Daerah khususnya Pemerintah Daerah Maluku Tengah karena sesungguhnya pengendalian hukum adat sendiri tidak berfungsi tanpa dukungan dari Pemerintah Daerah sebagai sebuah sistem pengendalian hukum adat itu sendiri. Jadi, dalam mengatasi konflik antar negeri di Kecamatan Jazirah Leihitu Kabupaten Maluku Tengah dibutuhkan sinergi dari seluruh stakeholder di tingkat provinsi dan kabupaten.
\end{abstract}

Kata kunci: Hukum adat, perkelahian, antar negeri

\section{PENDAHULUAN}

Masyarakat adalah penting didalam membuat seseorang lebih manusiawi dan mempertahankan kualitasnya sebagai manusia. Tanpa pengaruh masyarakat dan kelompok orang tidak akan dapat belajar berbicara atau bertingkahlaku sosial. Hilangnya hubungan kemasyarakatan dan kelompok dapat menjadi sebuah variable yang dapat menjelaskan kenapa seseorang melakukan kriminalitas. Disamping itu juga dapat menimbulkan adanya perilaku anti sosial atau perilaku asosial yang mungkin dapat menjadi faktor penyebab timbulnya kejahatan. Kejahatan merupakan suatu tindakan kriminal yang merupakan suatu bentuk dari perilaku menyimpang yang selalu ada dan melekat pada tiap bentuk masyarakat (Muladi dan Nawawi, 1984: 148). Menurut M.J.Saptenno, suasana kehidupan masyarakat Maluku yang selalu berinteraksi untuk memenuhi kebutuhan hidup, membangun tatanan kehidupan yang layak, selalu menuntut hak dan harus melaksanakan kewajiban merupakan dimensi dan dinamika kehidupan masyarakat yang harus menjadi dasar dan motivasi serta inovasi bagi pembentuk aturan hukum untuk memperjuangkan dan mewujudkannya (Ralahalu, 2012:318).

Setiap manusia mempunyai apa yang dinamakan perilaku (behavior) yakni suatu totalitas dari gerak motoris, persepsi, dan fungsi kognitif dari manusia. Salah satu unsur dari perilaku adalah gerak sosial (social action) yakni suatu gerak yang terikat oleh empat syarat yakni (Soekanto, 2012:6): (a) diarahkan untuk mencapai tujuan-tujuan tertentu; (b) terjadi pada situasi tertentu; (c) diatur oleh kaidah-kaidah tertentu; dan (d)terdorong oleh motivasi-motivasi tertentu. 
Perilaku kejahatan adalah hasil kerusakan sistem dan struktur sosial. Artinya, perilaku kejahatan akan muncul sebagai interaksi antara faktor personal dan faktor lingkungan yang harus dapat diidentifikasi. Secara sosiologis kejahatan merupakan suatu pola tingkah laku yang merugikan masyarakat (artinya ada terdapat korban) dan suatu pola tingkah laku yang mendapatkan reaksi sosial dari masyarakat (Mustafa, 2007:16). Ketika membicarakan kejahatan perlu juga mengidentifikasi pelaku dan korban. Pelaku adalah orang yang melakukan tindakan melanggar hak dan kesejahteraan hidup seseorang, sedangkan korban adalah orang yang terlanggar hak dan kesejahteraan hidupnya. Lokollo menandaskan, kejahatan dalam pelbagai bentuk dan manifestasi menampakan diri dalam tingkatan yang berbeda dalam intensitas, kuantitas, dan kualitas (Lokollo, Disertasi: 1988:159). Kejahatan itu ditimbang dalam hubungan dengan nilai-nilai sosial, aspek budaya, dan faktor struktur suatu masyarakat tertentu tanpa mengingkari adanya unsur dan aspekaspek yang bersifat universal.

Sahetapy berpendapat bahwa nilai-nilai sosial, aspek budaya, dan faktor struktural merupakan elemen-elemen yang terdapat dalam setiap masyarakat. Aspek budaya dan struktural merupakan dua elemen yang saling berpengaruh dalam masyarakat (Utari, 2012: 51). Oleh karena itu, kedua elemen tersebut bersifat dinamis sesuai dengan dinamisasi dalam masyarakat yang bersangkutan. Hal tersebut berarti bahwa pengaruh luar seperti ekonomi, teknologi, dan sebagainya mempengaruhi timbulnya kejahatan. Kejahatan berupa perkelahian merupakan perbuatan yang melawan hukum. Dari segi hukum pidana, dimana aturan-aturan yang jelas dalam berbagai undang-undang terutama hukum pidana, dilarang merusak harta orang lain, menganiaya, membunuh, karena bila dilakukan melanggar hukum negara dan diberikan sanksi. Namun, perkelahian yang terjadi antar negeri-negeri adat di Kecamatan Jazirah Leihitu Kabupaten Maluku Tengah hanya karena salah paham, tawuran antar pelajar lebih cenderung disebabkan kenakalan remaja, yang pada akhirnya membuat masyarakat melakukan perkelahian antar negeri.

Fenomena perkelahian antar negeri adat di Kecamatan Jazirah Leihitu Kabupaten Maluku Tengah, dapat ditemui seperti yang terjadi antara Negeri Hitu Lama dan Hitu Meseng, begitu pula yang terjadi antar Negeri Ureng dan Asilulu, juga yang terjadi antara Negeri Mamala dan Morela. Dalam sebuah konflik akan menimbulkan berbagai macam dampak (Dedi Kurniawan,Abdul Syani, 2014:4). Konflik yang terjadi berupa perkelahian yang berujung pada pembakaran rumah warga, selain itu timbul korban jiwa dan luka-luka pada kedua belah pihak. Konflik tersebut muncul sebagai akibat perselisihan batas diantara masing-masing negeri, dan pemicu lainnya seperti tawuran antar pelajar. Konflik ini meluas dan menyebabkan terjadinya penebangan dan pembakaran pohon cengkih milik penduduk negeri. Hal ini mengakibatkan hubungan diantara kedua negeri menjadi tegang.

Penyelesaian konflik yang terjadi antar negeri-negeri adat di Kecamatan Jazirah Leihitu Kabupaten Maluku Tengah, ada yang sudah tuntas tetapi ada pula yang belum tuntas. Dalam penyelesaian konflik maka tokoh adat dapat berperan sebagai hakim atau pemutus dan penengah atau mediator (Busroh, 2017:108). Fungsi Raja (Kepala Desa) sebagai pengendali hukum adat antar negeri belum sepenuhnya berfungsi dengan baik dan maksimal. Oleh karena ketidakmampuan Raja Negeri untuk mengendalikan suatu kondisi yang dapat memicu terjadinya perkelahian yang kemungkinan berdampak menjadi luas serta pemahaman tentang soal-soal penegakan hukum adat yang sistematik tidak dipahami dengan baik oleh Raja-Raja Negeri. Upaya pendekatan represif dengan mengandalkan kekuatan militer dan kerasnya sanksi hukum sekalipun justru tidak menyelesaikan masalah. Penanganan konflik disini mesti ditata secara arif, dengan memperhatikan berbagai potensi yang merupakan isu. Isu mana kemudian dianalisis dan hasilnya 
kemudian disusun sebuah kebijakan (policy), baik untuk kepentingan penegakan hukum maupun untuk kepentingan perlindungan masyarakat.

Berdasarkan fenomena yang telah dijelaskan diatas, maka permasalahan yang diangkat oleh penulis untuk dibahas adalah bagaimana cara menyelesaian konflik antar negeri di Kabupaten Maluku Tengah dengan memakai hukum adat.

\section{METODE PENELITIAN}

Metode Penelitian adalah tata cara bagaimana suatu penelitian akan dilaksanakan. Mengingat penelitian ini merupakan penelitian hukum, maka metode penelitian yang digunakan adalah metode penelitian hukum. Penelitian hukum merupakan proses untuk menemukan aturan hukum, prinsip-prinsip hukum maupun doktrin-doktrim hukum untuk menjawab isu-isu hukum yang dihadapi (Peter Mahmud Marzuki:35). Untuk menunjang penelitian ini maka penulis mempergunakan metode penelitian:

\section{Jenis Penelitian}

Penelitian tentang Kajian Hukum Adat Terhadap Konflik Antar Negeri di Maluku (Studi di Kecamatan Jazirah Leihitu Kabupaten Maluku Tengah) adalah penelitian Yuridis Sosiologis. Penelitian Yuridis Sosiologis adalah kehidupan hukum adat yang tidak tertulis, yang tidak dideskripsikan secara sistematis, faktual, dan akurat, mengenai sifat-sifat, karakteristik masyarakat, dan faktor-faktor tertentu yang menyebabkan perkelahian yang secara psikologi hukum dapat dengan mudah mengetahui perilaku kolektif dan mentalitas masyarakat yang selalu mempengaruhi terjadinya perkelahian antar negeri dimaksud.

\section{Tipe Penelitian}

Adapun tipe penelitian yang digunakan adalah deskriptif analitis yaitu memberikan gambaran terhadap objek yang diteliti melalui data atau sampel dan diolah atau dianalisis untuk diambil kesimpulannya.

\section{Lokasi Penelitian}

Dalam penelitian ini, lokasi yang digunakan sebagai lokasi penelitian adalah Kecamatan Jazirah Leihitu, Kabupaten Maluku Tengah, Provinsi Maluku.

\section{Sumber Data}

Dalam penelitian ini, jenis data yang digunakan adalah data primer yang dihasilkan dari penelitian lapangan yang diperoleh langsung dari responden penelitian yang terkait dengan pengendalian hukum adat terhadap perkelahian antar negeri. Dengan mengadakan studi/penelitian kepustakaan akan memperoleh data awal untuk dipergunakan dalam penelitian lapangan, dan data sekunder yang diperoleh dari penelitian kepustakaan terdiri dari:

1. Bahan Hukum Primer, berkaitan dengan masalah yang akan diteliti seperti Kitab UndangUndang Hukum Pidana (KUHP), Undang-undang Nomor 23 Tahun 2014, Undang-undang Nomor 7 Tahun 2012 dan Inpres Nomor 2 Tahun 2013. Peraturan Daerah Provinsi Maluku Nomor 14 Tahun 2015, Peraturan Daerah Kabupaten Maluku Tengah Nomor 1 Tahun 2006.

2. Bahan Hukum Sekunder, merupakan bahan hukum yang memberikan penjelasan dan petunjuk mengenai bahan hukum primer seperti buku-buku referensi, jurnal hukum dan hasil-hasil penelitian karya ilmiah yang relevan dengan penelitian ini. 
3. Bahan Hukum Tertier, sebagai bahan hukum penunjang yang mencakup petunjuk-petunjuk maupun penjelasan terhadap bahan hukum primer dan sekunder yaitu berupa kamus, ensiklopedia.

\section{Teknik Pengumpulan Data}

Pengumpulan data yang penulis lakukan dengan dua cara yaitu:

1. Penelitian Kepustakaan, yaitu pengumpulan data sekunder baik berupa peraturan perundang-undangan yang berlaku dan dokumen yang berkaitan dengan objek yang diteliti maupun teori-teori dan asas-asas hukum yang berkaitan dengan materi penelitian.

2. Penelitian Lapangan, yaitu pengumpulan data secara langsung dari pihak-pihak terkait dengan pengendalian hukum adat terhadap perkelahian antar negeri di Maluku agar memperoleh dan menghimpun data primer atau data yang relevan dengan objek yang akan diteliti.

\section{Teknik Analisa Data}

Data penelitian diolah dan dianalisis secara kualitatif yaitu menganalisa data berdasarkan kualitasnya lalu dideskripsikan dengan menggunakan kata-kata sehingga diperoleh bahasan atau paparan dalam bentuk kalimat yang sistematis dan dapat dimengerti, kemudian ditarik kesimpulan.

\section{HASIL DAN PEMBAHASAN}

\section{Perkelahian merupakan perbuatan melanggar sistem pengendalian hukum adat}

Dalam memenuhi kebutuhan hidupnya, tidak jarang terjadi benturan kepentingan antara manusia satu dengan manusia lainnya yang dapat menyebabkan terjadinya suatu kejahatan. Benturan kepentingan selalu saja menimbulkan kesalahpahaman dan merupakan akar permasalahan dari perkelahian antara individu dalam suatu interaksi sosial. Perkelahian antar negeri di Kabupaten Maluku Tengah (Kecamatan Jazirah Leihitu) merupakan perilaku masyarakat yang sulit ditinggalkan. Hal ini disebabkan pengaruh psikologis yang kuat dan selalu ada dalam jiwa masyarakatnya, sehingga bila terjadi konflik kecil saja maka timbul dorongan dari dalam jiwa untuk melakukan perkelahian antar negeri.

Perkelahian antar negeri di Kabupaten Maluku Tengah (Kecamatan Jazirah Leihitu) pelakunya mulai dari pelajar, mahasiswa, kelompok masyarakat yang biasanya hidup berdampingan dalam suatu wilayah tertentu, yang tentu saja menimbulkan korban yang tidak sedikit baik materi maupun non-materi. Permasalahan ini bukanlah fenomena baru dibeberapa kota besar di Indonesia, temasuk di Kabupaten Maluku Tengah (Kecamatan Jazirah Leihitu). Perkelahian antar warga yang merembet hingga terjadi perkelahian antar negeri yang dilakukan oleh individu-individu yang merangkum diri dalam suatu atau beberapa kelompok, memiliki ciri yang unik dibandingkan dengan tindak pidana lainnya. Keunikan tersebut antara lain bahwa pada saat terjadinya perkelahian kita dapat menyaksikan keterlibatan massa, namun pada saat pihak yang berwajib turun tangan, dalam kenyataannya hanya segelintir orang saja dari massa pelaku yang diproses. Sementara penyebab dari perkelahian antara warga yang terjadi saat itu hanyalah hal yang sepeleh dan kebanyakan belum diketahui secara pasti awal mula perkelahian sehingga pencegahannyapun hanya sebatas mendamaikan dan mengusut pelaku-pelaku perkelahian.

Pengaruh psikologis generasi muda cukup kuat dalam mendorong terjadinya perkelahian, remaja dewasa memang bertendensi kearah pertikaian dan penganiayaan (Bawengan, 1977:61). Pada umumnya merekalah yang memulai melakukan perkelahian dan pada akhirnya melibatkan masyarakat secara keseluruhan dalam satu negeri. Perbuatan itu merugikan orang lain, bahkan menyebabkan penganiayaan, pengrusakkan dan kematian. Kekacauan selama konflik dan sesudah konflik mendorong terjadinya pertumbuhan kejahatan (Bonger, terj.R.A.Koesnan, 1981:34). 
Bagi masyarakat di Kecamatan Jazirah Leihitu Kabupaten Maluku Tengah perkelahian merupakan kebiasaan yang terjadi pada setiap tahun. Faktor lain adalah tidak dimilikinya pekerjaan tetap sehingga membuat kegiatan-kegiatan yang tidak bermanfaat, kesalapahaman dalam masyarakat dan beredarnya informasi yang tidak benar sehingga memicu terjadinya perkelahian. Dorongan melakukan perkelahian merupakan perilaku psikologis masyarakat untuk cepat berpartisipasi sehingga mendorong keberanian dan semangat melakukan perkelahian dengan tindakan cepat dan mengantisipasi bila ada serangan dari pihak lain. Jadi, rasa persaudaraan yang tinggi kemudian ikatan marga yang membuat mereka merasa solidaritas marga terbawa dalam solidaritas negeri. Selain itu, yang paling cepat menciptakan masyarakat dalam kerja sama bila terjadinya perkelahian adalah isu.

Sering terjadinya perkelahian akibat pembinaan dari pihak-pihak terkait salah satunya adalah organisasi pemuda tidak berfungsi secara baik sehingga mental generasi muda tidak dibentuk untuk menghindari kegiatan-kegiatan negatif. Perkelahian antar negeri di Jazirah Leihitu sebenarnya bermula dari persoalan-persoalan yang sebenarnya dapat diselesaikan secara musyawarah, melalui pendekatan kekeluargaan maupun agama, namun karena masyarakat selalu mengandalkan fisik setiap terjadi sengketa antar individu yang satu dengan individu yang lain dan antar negeri satu dengan negeri yang lain. Negeri-negeri di Kecamatan Jazirah Leihitu Kabupaten Maluku Tengah pada umumnya melakukan perkelahian hanya dilatarbelakangi oleh hal-hal yang bersifat pribadi, kemudian menjadi luas dan melibatkan masyarakat secara keseluruhan.

\section{Pengendalian hukum adat tidak bisa berjalan tanpa politik pemerintah daerah}

Hal yang penting juga dalam upaya penanganan konflik adalah kemitraan antara semua pihak yang dilandasi oleh komitmen dari visi dan misi yang harmonis dan sinergis (Sukardi, 2016:81). Tidak hanya peran POLRI dan TNI guna menyelesaikan konflik antar dua negeri bertetangga di Kabupaten Maluku Tengah (Kecamatan Jazirah Leihitu), tapi dibutuhkan stakeholder baik pemerintah provinsi maupun pemerintah kabupaten. Perkelahian antar negeri Mamala-Morela adalah juga tanggungjawab Pemerintah Kabupaten Maluku Tengah. Lembaga-lembaga ini bertanggungjawab dalam mengambil langkah-langkah implementasi yang efektif dalam menyelesaikan kekisruhan yang berulang kali terjadi. Kunci utama penyelesaiannya adalah harus ada kesadaran untuk menyelesaikan konflik yang tumbuh dari kita semua, khususnya dari masyarakat kedua negeri itu sendiri, didukung oleh pemerintah daerah sebagai pemegang staf dan dibantu TNI-POLRI, tokoh adat, agama, dan para cendekiawan.

Undang-undang Nomor 23 Tahun 2014 tentang Pemerintah Daerah, secara nyata mengatur pula mengenai desa atau dengan nama lain sebagai kesatuan masyarakat hukum yang memiliki batasbatas wilayah yang berwenang untuk mengatur dan mengurus kepentingan masyarakat setempat, berdasarkan asal usul dan adat istiadat setempat yang diakui dan dihormati dalam sistem Pemerintahan Negara Kesatuan Republik Indonesia. Tanggung jawab Pemerintah Kabupaten Maluku Tengah yang diamanatkan dalam Undang-undang Nomor 23 Tahun 2014 bahwa dalam penyelenggaraan otonomi daerah, daerah mempunyai kewajiban melindungi masyarakat, menjaga persatuan, kesatuan, dan kerukunan nasional, serta keutuhan Negara Kesatuan Republik Indonesia. Tanggungjawab Pemerintah Kabupaten Maluku Tengah juga perlu dipikul berdasarkan Undangundang Nomor 7 Tahun 2012 tentang Penanganan Konflik, serta INPRES Nomor 2 Tahun 2013 tentang Penanganan Gangguan Keamanan.

Penetapan kembali negeri dengan dikeluarkannya Peraturan Daerah Provinsi Maluku Nomor 14 Tahun 2005 tentang Penetapan Kembali Negeri Sebagai Persekutuan Masyarakat Hukum Adat 
Dalam Wilayah Pemerintahan Provinsi Maluku mempunyai implikasi bahwa di Maluku pada umumnya masih dikenal persekutuan-persekutuan masyarakat hukum adat yang disebut dengan negeri atau sebutan nama lain. Penyebutan "negeri" tidak dimaksudkan bahwa pemerintah provinsi lalu mengklaimnya sebagai satu-satunya persekutuan masyarakat hukum adat di Maluku, tetapi masih diakui juga beberapa sebutan/nama diberbagai daerah lainnya, seperti Maluku Tenggara dikenal "ohoy" dan "ratschap", Maluku Tenggara Barat "pnue", "lekhe", "momor", "negeri", Kepulauan Aru "pnua", "kampung", di Maluku Tengah dan Pulau Buru "negeri". Persekutuan masyarakat hukum adat lebih dikenal dengan sebutan "negeri" ketimbang sebutan lain.

Peran kearifan lokal menjadi sangat penting (Susanto, 2010:274). Dari perspektif politik kultural, penetapan atau penyebutan "negeri" oleh pemerintah provinsi di Maluku di dalam peraturan daerah, menunjukan sebuah identitas dan jati diri orang di Maluku, bahwa kita punya adat istiadat yang masih eksis, kita punya kearifan budaya lokal yang masih dijunjung tinggi. Eksistensi pemerintahan adat dan pranata sosial budaya masyarakat hukum adat di Maluku sejak dahulu hingga sekarang masih diakui. Hal ini terbukti dengan masih adanya penyebutan pranata-pranata adat, seperti negeri. Penyelenggaraan pemerintahan adat lebih didominasi oleh pelaku turun temurun, seperti raja, hanya dijabat atau dipilih/diangkat dari keturunan yang memerintah dan sebagainya.

Penyelesaian perselisihan dalam Pasal 64 Perda Kabupaten Maluku Tengah Nomor 1 tahun 2006 tentang Negeri, menyebutkan bahwa:

1. Penyelesaian sengketa dibidang hukum adat termasuk sengketa petuanan dapat ditangani dan diputuskan oleh Saniri Negeri atau Dewan Adat yang khusus di bentuk untuk itu sesuai kewenangan menurut ketentuan hukum adat setempat, sepanjang tidak bertentangan dengan ketentuan perudang-undangan yang berlaku.

2. Pemerintah daerah dan/atau aparat penegak hukum lainnya dapat berperan sebagai mediator dalam penyelesaian sengketa sesuai ketentuan dalam ayat (1).

3. Dalam hal terjadinya suatu sengketa dibidang hukum adat yang berdampak luas dan dapat mengganggu ketertiban umum dan keamanan pemerintah daerah dan/atau aparat penegak hukum lainnya dapat mengambil langkah-langkah untuk mengatasinya baik diminta maupun tidak diminta.

Terhadap pengendalian hukum adat perlu adanya upaya atau cara yang diatur berdasarkan normanorma hukum adat untuk mencegah hal-hal yang tidak diinginkan. Hal mana dimaksud bahwa dalam bentuk upaya mengendalikan perkelahian atau suatu keadaan yang tidak diinginkan serta mengganggu keamanan dan kenyamanan masyarakat, maka kesepakatan antar dua negeri, antar soa, antar raja, tertuang dalam norma hukum adat sebagai peraturan negeri yang berlaku dan mengikat bagi negeri itu sendiri dan masyarakatnya.

R.Soesilo menulis bahwa usaha-usaha pencegahan kejahatan yang bersifat preventif (sebelum tindak pidana terjadi), yakni (Soesilo, 1976:95):

1. Mengadakan usaha-usaha dan tindakan-tindakan untuk mencegah jangan sampai terjadi perbuatan-perbuatan anti sosial oleh anak-anak dengan masyarakat untuk memenuhi kebutuhan pokok anak-anak itu, misalnya makan, cinta kasih orang tua, dan lain sebagainya.

2. Keikutsertaan masyarakat untuk berkecimpung dalam organisasi masyarakat dalam usaha menyelenggarakan kegiatan-kegiatan berupa olahraga, kesenian, rekreasi, dan sebagainnya.

3. Mengadakan perondaan-perondaan ditempat dimana anak-anak berkumpul, rumah perjudian, tempat-tempat penjualan minuman keras dan sebagainya. 
4. Membubarkan dan menyingkirkan anak-anak dari tempat perjudian dan miras dan sebagainya.

Beberapa cara yang ditempuh dalam tindakan represif atau atau setelah tindak pidana tersebut terjadi antara lain:

1. Menjatuhkan hukuman yang semaksimal mungkin terhadap para pelaku perkelahian tersebut;

2. Memberi upaya penyuluhan hukum, agama, moral dan etika kepada para tahanan dan narapidana.

3. Memberikan pembinaan dan latihan kepada narapidana selama dalam masa tahanan dalam lembaga kemasyarakatan dnegan berbagai keterampilan yang memberikan kemungkinan terhadap narapidana agar bias mandiri setelah menjalani masa hukuman.

4. Memberikan penerangan kepada masyarakat untuk tidak mengucilkan para bekas narapidana.

Dalam upaya pencegahan kejahatan, strategi-strategi pencegahan dan penanggulan kejahatan yang harus dilakukan polisi 4 unsur sebagai berikut:

1. Consultation, dapat diartikan sebagai memperdalam hubungan dan penemuan secara teratur dengan kelompok-kelompok yang ada.

2. Adaption, merupakan suatu upaya memahami karakteristik suatu wilayah dengan isinya, baik kejahatan, struktur masyarakat atau sumber daya yang ada.

3. Mobilisation, merupakan suatu asumsi bahwa pencegahan kejahatan tidak mungkin hanya dilakukan oleh aparat kepolisian. Sedangkan misi pokok dari mobilisasi adalah memberikan kepemimpinan dan dukungan profesional untuk mendorong dan memperbaiki usaha masyarakat guna mengembangkan suatu program kooperatif dan seimbang guna menghadapi tingkah laku menyimpang dan melanggar hukum.

4. Problem Solving (solusi permasalahan), sebagai reaksi terhadap kejahatan dan keadaan darurat lain setelah hal tersebut terjadi, aparat kepolisian mulai mempelajari kondisi-kondisi yang menimbulkan munculnya panggilan layanan pengaduan, menyusun rencana untuk untuk membetulkan kondisi ini dan dan mempelopori dalam mengevaluasi dan melaksanakan tindakan-tindakan perbaikan.

Kehidupan sosial memberi patokan-patokan atau pedoman-pedoman mengenai apa yang salah atau apa yang benar, apa yang normal dan apa yang abnormal (Soekanto, 2012:80). Dengan adanya upaya penanggulangan kejahatan secara preventif, represif, maupun rehabilitasi diharapkan agar untuk masa kedepannya segala bentuk kejahatan dapat ditekan tingkat perkembangnnya sehingga masyarakat dapat hidup tentram, damai, dan sejahtera. Dalam pengendalian sosial, lembagalembaga yang ada dalam masyarakat cukup berperan. Lembaga-lembaga yang bertujuan untuk memenuhi kebutuhan-kebutuhan pokok manusia pada dasarnya mempunyai peran yakni memberikan pedoman pada anggota masyarakat.

Selain perda-perda tersebut diatas berisi tentang penyelenggaraan pemerintahan daerah, perda tersebut juga merupakan payung bagi penyelesaian kasus-kasus perkelahian antar negeri di Maluku. Contohnya, kesepakatan tiga negeri di Jazirah Leihitu, Kecamatan Leihitu Barat, seperti Negeri Lima, Negeri Kaitetu, dan Negeri Seith, yang intinya adalah menjaga ketenteraman dan keamanan antar negeri. Demikian juga beberapa kesepakatan penyelesaian konflik dibeberapa negeri seperti antar Negeri Noloth dan Negeri Itawaka dengan tugu perdamaian, juga antara negeri Ouw dan Negeri Ulath. Terjadinya norma dan aturan haruslah melalui suatu proses, misalnya kesepakatan bersama. Butuh upaya keras melalui sinergitas semua pihak dengan pendekatan dari berbagai sisi kehidupan. Legitimasi dan kekuatan hukum dapat dicapai, oleh karena itu perlu dibuat perda oleh Pemerintah Daerah untuk berlaku disemua negeri adat di Maluku yang digunakan untuk menjadi payung, ketika menghadapi permasalahan yang sama. 


\section{KESIMPULAN DAN SARAN}

Berdasarkan uraian yang dilakukan, maka dapat disimpulkan bahwa hukum adat dapat dipakai sebagai sarana pengendalian terhadap konflik antar negeri di Maluku dengan intervensi atau campur tangan pemerintah daerah melalui perkuatan fungsi-fungsi lembaga adat, seperti raja, saniri negeri, polisi negeri adat (kewang laut,kewang darat,kewang batas-batas tanah dusun/negeri, dan lain-lain sepanjang dibutuhkan), peningkatan kerja sama antar negeri/antar raja, saniri negeri, kewang negeri,perkumpulan kaum ibu antar negeri,perkumpulan pemuda atau pelajar, peningkatan pemahaman ajaran keputusan (Beslissingen Leer) dari van Vollenhoven Ter Haar bahwa satu kali keputusan raja itu adalah "kebiasaan" dan itu adalah "hukum adat" dengan sanksinya yang kuat, penerapan atau sosialisasi nilai-nilai positif seperti PELA GANDONG dan HIDOP ORANG BASUDARA (hidup orang bersaudara dan atau nama lain).

\section{Saran}

Bertolak dari kesimpulan yang telah dikemukan diatas, maka dapat disarankan bahwa hukum adat dapat dipakai sebagai sarana pengendalian terhadap perkelahian antar negeri di Kabupaten Maluku Tengah dengan intervensi atau campur tangan pemerintah daerah untuk dilanjutkan dalam pembuatan peraturan daerah maupun peraturan negeri atau desa.

Ucapan Terima Kasih (Acknowledgement)

Peneliti mengucapkan terima kasih kepada seluruh pihak yang sudah bersedia berpartisipasi dalam penelitian kali ini.

\section{REFERENSI}

Busroh, F. F. (2017). Peranan tokoh adat sebagai mediator sosial dalam menyelesaikan konflik agraria yang melibatkan masyarakat adat multikultur di indonesia (Perspektif Kajian Sosiolegal Reseach). Jurnal Hukum Mimbar Justitia, 108 Vol. 3 (1).

Dedi Kurniawan dan Abdul Syani. (2014). Faktor penyebab, dampak, dan strategi penyesaian konflik antar warga di kecamatan way panji kabupaten lampung selatan. Jurnal Sosiologi, 4 Vol. 15 (1).

G.W.Bawengan. (1977). Masalah kejahatan dengan sebab dan akibat. Jakarta: Oradnya Paramita.

J.E.Lokollo. (1988). Perkembangan pidana denda di Indonesia (Disertasi doktoral). Fakultas Hukum Universitas Airlangga, Surabaya.

Marzuki, P. M. (2005). Penelitian hukum. Jakarta: Kencana Predia Media Group.

Muladi dan Barda Nawawi. (1984). Teori-teori dan kebijakan pidana. Bandung: Alumni.

Mustafa, M. (2007). Kriminologi. Depok: FISIP UI Press.

Ralahalu, K. A. (2012). Berlayar dalam ombak, berkarya bagi negeri, pemikiran anak negeri untuk maluku. Ambon: Ralahalu Institut.

Soekanto, S. (2012). Hukum adat di Indonesia. Jakarta: Raja Grafindo Persada.

Soesilo, R. (1976). Ajaran kejawen-philosofi dan perilaku. Jakarta: Yayasan Ursula. 
Sukardi. (2016). Penanganan Konflik Sosial Dengan Pendekatan Keadilan Restoratif. Jurnal Hukum dan Pembangunan, 81 Vol. 46 (1).

Susanto, A. F. (2010). Ilmu hukum non sistematik: Fondasi filsafat perkembangan ilmu hukum Indonesia. Yogyakarta: Genta Publishing.

Utari, I. S. (2012). Aliran dan teori dalam kriminologi. Semarang: Thafa Media.

W.A. Bonger (diterjemahkan oleh R.A.Koesnan). (1981). Pengantar tentang kriminologi. Jakarta: Ghalia Indonesia. 